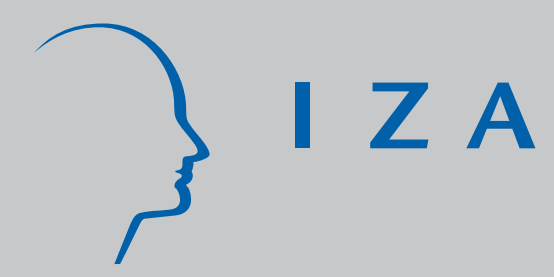

IZA DP No. 3029

An Experimental Investigation of Age Discrimination in the English Labor Market

Peter A. Riach

J udith Rich

September 2007 


\title{
An Experimental Investigation of Age Discrimination in the English Labor Market
}

\author{
Peter A. Riach \\ IZA (Research Fellow) \\ Judith Rich \\ University of Portsmouth \\ and IZA
}

\section{Discussion Paper No. 3029 \\ September 2007}

\author{
IZA \\ P.O. Box 7240 \\ 53072 Bonn \\ Germany
}

Phone: +49-228-3894-0
Fax: +49-228-3894-180
E-mail: iza@iza.org

Any opinions expressed here are those of the author(s) and not those of the institute. Research disseminated by IZA may include views on policy, but the institute itself takes no institutional policy positions.

The Institute for the Study of Labor (IZA) in Bonn is a local and virtual international research center and a place of communication between science, politics and business. IZA is an independent nonprofit company supported by Deutsche Post World Net. The center is associated with the University of Bonn and offers a stimulating research environment through its research networks, research support, and visitors and doctoral programs. IZA engages in (i) original and internationally competitive research in all fields of labor economics, (ii) development of policy concepts, and (iii) dissemination of research results and concepts to the interested public.

IZA Discussion Papers often represent preliminary work and are circulated to encourage discussion. Citation of such a paper should account for its provisional character. A revised version may be available directly from the author. 
IZA Discussion Paper No. 3029

September 2007

\section{ABSTRACT}

\section{An Experimental Investigation of Age Discrimination in the English Labor Market}

Carefully-matched pairs of written job applications were made to test for age discrimination in hiring. A twenty-one year-old and a thirty-nine year-old woman applied for jobs where a "new graduate" was sought; men aged twenty-seven and forty-seven, inquired about employment as waiters; women aged twenty-seven and forty-seven, inquired about employment in retail sales. The rate of net discrimination against the older graduate, and against the older waiters in their London inquiries, correspond to the highest rates ever recorded anywhere, by written tests, for racial discrimination. There was a statistically significant preference for the older applicant in retail sales.

JEL Classification: J71, C93

Keywords: age, discrimination, employment, field experiment, hiring

Corresponding author:

Judith Rich

Department of Economics

University of Portsmouth

Richmond Building

Portland Street

Portsmouth PO1 3DE

United Kingdom

E-mail: judy.rich@port.ac.uk 
“He looks old to be a waiter” (White Teeth)

\section{Introduction}

The growing interest in field experiments, as a method of empirical investigation in economics, is demonstrated by the special issue of The BE Journal of Economic Analysis and Policy (Advances), (2006, 6, issue 2) which is dedicated to field experiments. The first field experiment of discrimination in employment, which used pairs of matched, written job applications, was undertaken in the 1960s by Jowell and Prescott-Clarke (1970). They developed the technique to investigate racial discrimination in employment in England. The first time this experimental method was applied to investigate sexual discrimination in employment was in Melbourne during the 1980s (Riach and Rich 1987). The measurement of discrimination by making matched, written job applications has been received with approbation in the academic journals, for example - in a survey of evidence on discrimination, Darity and Mason stated "This (correspondence testing) is impressive direct evidence of discrimination from a powerful test procedure” (Darity and Mason 1998, p. 81).

Although it originated almost forty years ago, there has been virtually no application of this technique to measuring the extent of age discrimination in employment. This is surprising, given the widespread contemporary concern about the economic implications of the ageing population in Western countries, and the frequent recommendation that the only viable solution to the consequent "pensions' crisis" is an extended working life. For example the Organisation for Economic Co-operation and Development (OECD), referring to the United Kingdom - “... in 2050, for every person over the age of 65, there will be only 2.1 individuals of working age compared to 3.7 in 2003” (OECD 2004, p. 36). The British Government's response to this 
impending demographic difficulty came in a Green Paper issued in 2002 by the Department of Work and Pensions; Simplicity, security and choice: Working and saving for retirement. Amongst other observations it included; "Increasing employment among older workers is essential if we are to address the pensions challenge. Working longer can dramatically reduce the rate at which people need to save for their retirement” (Department for Work and Pensions 2002, Cmd. 5677, p. 93 - emphasis added).

It is the case, though, that there is a significant challenge in applying the experimental technique to age discrimination; this is the obvious variation in human capital across the generations. The logic of this experimental technique, as innovated by Jowell and Prescott Clarke, is to design the test so as to control strictly for human capital components such as education, qualifications, skills and experience, and so that the only distinguishing feature of the two job applicants is the characteristic, such as race or sex, which is being tested. The influence of race or sex on hiring decisions is consequently isolated. In the case of age there must inevitably be a variation in the job experience of the different age groups, and therefore a difficulty in determining whether any employment preference is attributable to a profit-maximizing response to differential human capital or to prejudice. The one economist who has applied the technique to age, Bendick (1996 and 1999), attempted to deal with this issue by having older applicants who had spent 25 years in some unrelated activity, such as child-raising, military service or public school teaching, which generated no relevant experience for the employment being tested. This is a highly artificial construct and leads to uncertainties; for instance, do employers rate experience between ages 40 and 
50 as equivalent to experience between ages 25 and 35? Also it is not a realistic basis for policy development as virtually no older workers fit such a pattern.

In our paper "Field Experiments of Discrimination in the Market-Place” (Riach and Rich 2002) we recommended that instead of adapting job applicants to the technique, the technique should be adapted to the special case of older applicants. In other words, to accept that the job experience component of human capital does vary between different groups and have realistic candidates make applications, but to control for all other dimensions of human capital.

A frequent accusation against older applicants is that they are less mentally able/flexible and less physically active than their youthful competitors; “... numerous surveys and research conducted in the past 15 years point to negative employer perceptions vis-à-vis older workers with respect to their productivity, cost, work motivation, health, receptiveness towards training and ability to cope with technological and organisational change” (OECD 2004, p. 97; see also Purcell et al. 2003, pp. 3-4). However the objective scientific literature is to the contrary; "The finding from more than 100 research investigations is that there is no significant difference between the job performance of older and younger workers” (Warr 1994, p. 309).

We decided to confront such ageist attitudes by presenting older applicants who were not more than forty-seven, who were engaged in strenuous physical activity, such as competitive squash and cycling, and who demonstrated mental flexibility by an up-todate interest in computers and information technology. In other words we controlled 
for the older candidate's mental and physical capacities, but not for their length of experience. In which case, if a preference were found for younger applicants with twenty years less experience, it would indicate a very significant level of prejudice against older applicants. On the other hand, if we were to find a preference for the older workers in such circumstances it could be interpreted as an economically rational response to human capital superiority, rather than prejudice against youth. The OECD recognises that; “...age discrimination is neither overt nor easily measured” (OECD 2004, p. 98). This is a challenge which we now address; what follows is the first realistic attempt to measure age discrimination by using the experimental technique of forwarding matched, written applications.

\section{The experiment}

The intention was to have pairs of job applicants who were carefully-matched in all respects except in the experience which inevitably goes with age. An implication of this approach is that jobs with a career hierarchy were ruled out of the investigation. For instance, academics in their mid-twenties would be applying for different posts to those in their mid-forties: the former would be applying for post-doctoral fellowships or lectureships, whilst the latter would be applying for Chairs or Deanships. This is not to say that age discrimination may not be alive and well in academia, or in law, or in the civil service, but instead that it cannot be investigated by the technique of paired mail applications. We have chosen occupations where it is realistic to expect that applications will come from candidates aged twenty years apart.

There are two techniques for applying this experimental method. The first is to respond to advertized vacancies, as innovated by Jowell and Prescott-Clarke in 1969, 
and surveyed by Riach and Rich (2002). The second is to conduct the investigation by forwarding unsolicited job inquiries to a group of employers in some occupation, as innovated by Fidell in 1970 and surveyed by Riach and Rich (2004b). The former procedure confronts the employer with simultaneous pairs of fictitious job applications at a time when he/she has initiated recruitment and they will be dealt with during the normal hiring process, but the application and observation rate, and therefore the duration of the study, is dependent on the state of the labor market. The latter procedure is more expedient; all that is required is an appropriate listing of employers in a particular occupation, and two mailings about a month apart, if the intention is to test matched pairs and if suspicion on the part of employers is to be allayed. This procedure is more appropriate in occupations where inquiries are customarily initiated from the supply side and in small business, so ensuring the inquiry is likely to be answered by the same person who normally takes hiring decisions. As inquiries must arrive at least a month apart there is some randomness in the extent to which they will coincide with a vacancy, therefore there can be less expectation of "equivalent treatment” (both candidates being offered interviews) than with the first procedure. Nevertheless, if in the first mailing fifty per cent of inquiries go from candidate $\mathrm{A}$ and fifty per cent from candidate $\mathrm{B}$, with reversal in the following month, this variation in timing will not bias the overall outcome of the experiment: i.e. there is control by age for the timing of application receipt.

We decided to apply both techniques in this study. In England we applied to advertized vacancies for new graduates in those positions where a "degree in general” was the prerequisite for employment, rather than any specific degree. Vacancies were obtained from the Saturday Guardian and from various web-sites 
(www.jobs.guardian.co.uk; www.topjobs.co.uk; www.monster.co.uk). Entry into the profession of Chartered Accountancy is by application to an authorised training firm, consequently such firms expect to receive, without advertisement, a steady flow of inquiries. We also had our new graduates apply to all such firms in England. One of our new graduates was female and aged twenty-one; the other was female and aged thirty-nine i.e. an individual euphemistically designated in Britain as a "mature age" graduate. The latter applicant had worked for eleven years as a secretary and spent five years in full-time child-rearing before entering university. She was divorced with a child of ten to indicate that pregnancy was likely to be a thing of the past.

We chose this area of employment because of its contemporary relevance; in 2002/03 there were 95,590 female students over thirty in English universities (20.4 percent of total students) and the universities actively recruit this age group (Higher Education Statistics Agency 2002/03, unpublished data). An additional reason for targeting a 39 year-old applicant was to explore the possibility of obtaining some experimental confirmation of the survey evidence which suggests that age discrimination can impact at a quite early age; e.g. "In a survey of over 1000 people the Chartered Institute of Personnel and Development found that ... 1 in 4 think that employers are not interested in employing people over age 40” (Third Age Employment Network 2003). In 1996 a survey of employers found evidence that age discrimination started at 42 (Penna Sanders and Sidney 2002).

In an experimental investigation of age discrimination, for the reasons discussed above, it is not possible strictly to alternate the résumés, as is done in race and sex experiments, but in all non age-related characteristics the résumés of "new graduates" 
were alternated. In half the applications the older applicant was a law graduate from $\mathrm{X}$ and in the other half she was an economics graduate from Y. We could not use the names of genuine educational institutions or employers in the résumés for two reasons. First there is the risk of detection if an employer were to make direct contact with a genuine company or university falsely cited in a résumé. Secondly an educational institution might take legal redress against a party falsely claiming to possess one of its awards. We decided to deal with this difficulty by inventing fictitious universities and employers. Just such an approach had been adopted in the International Labour Office's investigation of racial discrimination in the German labor market: fictitious schools and universities were invented (Goldberg et al. 1996). There are approximately one hundred universities in Britain and all but a handful have locational names; either of a city or a county. We therefore chose an English city and county which did not have universities, but which quite plausibly might, and used them in the résumés of our “new graduates”. There was a flood of new universities in the decade prior to these tests. In 1992 twenty polytechnics became universities with names like De Montfort, South Bank, Liverpool John Moores and London Guildhall. Since then there has been a steady trickle of additions with Chichester, Southampton Solent and Thames Valley amongst those acquiring universities. If counties such as Hertfordshire and Staffordshire have universities why might not Herefordshire and Shropshire? If towns like Loughborough, Bournemouth and Brighton have universities is it not conceivable that Ipswich and Salisbury have universities? We therefore believe that employers recruiting graduates would be unlikely to have a definitive knowledge of the current list of universities. In the case of current and former employers we simply specified their field of activity, such as merchant banking or chartered surveying. University careers officers and a Course Leader in 
Business Studies provided advice on the personal profiles used for the graduates' résumés, and their realism and efficacy is confirmed by the fact that we did obtain responses from very large firms and major recruitment agencies.

Cultural and sporting interests were chosen to be interchangeable because of the practice of reversing résumés. They were also deliberately chosen to suggest that the older applicant had no stereo-typical ageist traits; the interchangeable interests included classical and contemporary dance, playing squash and language classes.

We sent unsolicited inquiries about possible job openings for male waiters to four hundred and seventy hotels and restaurants throughout England (two hundred and twenty in London and two hundred and fifty across the rest of the country). One applicant was twenty-seven and the other was forty-seven. We chose this area of employment because it is one where supply-side inquiries are customary, and because it is an area of small business where any inquiry is likely to find its way to those who normally take the hiring decision.

It was not possible to perform any reversal of résumés in this case as, unlike our “new graduate” applicants, the education of waiters could not have been undertaken simultaneously. Both candidates had completed year eleven of school, but in the case of the older candidate the prevailing award in England was General Certificate of Education (GCE) at Ordinary (O) level, whereas in the case of the younger candidate it was General Certificate of Secondary Education (GCSE). Both candidates had included English and Mathematics in their awards. In this case we invented fictitious restaurant names for current employers. The efficacy of this tactic in particular, and 
the content of our résumés in general is confirmed by the receipt of positive responses from some of London's most expensive and fashionable restaurants. "Interests” were chosen to demonstrate the older applicant's physical fitness, and capacity to cope with modern technology. The "interests" included competitive squash and internet usage; also, computing had been studied at evening class. The résumés of waiters were prepared in conjunction with advice from the head waiter of a two-star restaurant in London. In any one posting half the inquiries went from the older applicant and half from the younger, with reversal in the following month. The résumés used for the waiters are included in the Appendix.

We used an identical procedure in making inquiries about possible employment in three hundred female clothing stores in London In this case one female applicant was twenty-seven and the other forty-seven; fictitious names were invented for the retail shops where they currently worked as assistant mangers. We chose to include this area of employment because it is one of small business, where the inquiry is likely to be dealt with by the person who normally takes hiring decisions. An additional reason is that there is anecdotal evidence in England that retail sales is an area where some employers do deliberately target older workers. The large “do-it-yourself” retailer, B\&Q, is noted for hiring older employees because of the benefit which their experience provides customers.

Once again, the relevant content of our résumé in general is confirmed by the receipt of positive responses from some of London's more expensive and fashionable retail shops and from major High Street chains. A former senior personnel manager of a major retail chain advised us on the résumés for this occupation. In this case the 
“Interests” chosen to demonstrate the older candidate’s physical fitness and mental agility were competitive tennis, the internet and learning Italian. Computer usage had been pursued at evening class.

The three pairs of English résumés were also vetted by an experienced employment consultant who specialises in advising older job applicants. We applied by surface mail and cited both an email and postal address for responses. The postal addresses were in comparable socio-economic districts of central London, approximately one mile apart. We have always been very careful to retain documentation of our research, so we were careful to print off applications and replies, so hard copies could be filed. Positive responses via email or surface mail were dealt with promptly and courteously with a reply explaining that alternative employment had already been secured.

The one publication where the ethical considerations involved in this deceptive procedure are dealt with, and compared with research activity in psychology, sociology and laboratory-experimental economics, is Riach and Rich (2004a). The alternative, non-deceptive, techniques for measuring discrimination have encountered difficulties. Surveys of attitudes towards target groups in the labor market are not likely to produce honest and accurate responses, as demonstrated by La Piere’s classic study. In 1934 he travelled through the USA with a Chinese couple and gained admittance to all except one of 241 hotels and restaurants approached. In response to questionnaires sent six months later to the same establishments, over 90 per cent replied they would not accept Chinese guests. (La Piere 1934) The econometrician’s application of regression analysis to published data to deduce discrimination, pioneered by Blinder (1973) and Oaxaca (1973) has been subject to considerable 
criticism, which revolves around the specification of the model and the choice of independent variables; see for example (Gunderson 1989) On the other hand, carefully-designed deceptive field experiments can provide an unequivocal measure of discrimination.

\section{The results}

The outcome of this experiment is set out in Table 1 in a format which follows McIntosh and Smith (1974, p. 13) and which has since been adopted in field experiments across Europe; e.g. Brown and Gay (1985); Bovenkerk (1992, pp. 26, 31) (see Riach and Rich 2002, pp. F486-F491). Column 4 shows the number of occasions when one or both applicants received a favorable response; by post, telephone, fax or email. This total is divided as follows: column 5 shows occasions when both received favorable responses (equal treatment); column 6 shows occasions when only the younger received a favorable response (discrimination against the older); and column 7 shows occasions when only the older received a favorable response (discrimination against the younger). Column 8 is net discrimination; that is 7 minus 6 , so that it is positive when the older applicant encountered more discrimination than the younger applicant. The statistical significance of any finding of net discrimination was determined by the application of the chi-square test. The data were categorised as accepted /rejected for two applicants in a 2*2 contingency table (Riach and Rich 2002, pp. F493 - F496). A comparison with British experimental results for race and sex discrimination is provided in Table 2. The rate of net discrimination against the older graduate applicant of 59.6 percent is one of the highest ever recorded. The highest net rate of discrimination ever previously recorded by the written experimental method was 66.7 percent against Antilleans in France in 1977 (Riach and Rich 2002, Table 4, 
p. F500). In view of the encouragement given by government for people to retrain, and by universities for mature-age women to enrol, this result is quite disturbing. Our older female graduate had an equivalent degree, no greater likelihood of pregnancy and one might have thought that her life experience would have enhanced her human capital and employability. On the contrary, we had one reply which explained "I wanted to be honest with you, our client is looking for recent graduates who are looking for their first job. You obviously have substantially more experience than this and being honest I feel that it would be a waste of your time to take your application any further. Sorry if this sounds harsh but we do believe in being honest with people”. (The younger applicant received a positive response: information on the job, and a request to complete a maths test and a questionnaire).

We report, in Table 3, the results for the sub-set of graduates, whose applications were to employers who possessed the imprimatur of "Investors in People". The net rate of discrimination in the case of these employers was 46.2 percent, which was statistically significant at the 0.01 level. The Home Page of this organization states; "Investors in People Standard is a straightforward, proven framework for delivering business improvement through people...” (Investors in People 2005). It also states on the page; Recruitment and Selection Model-Any Questions? “The Recruitment and Selection Model focuses specifically on good recruitment and selection practices, and how they impact on performance”. Apparently some members of Investors in People believe that "good recruitment and selection practice" involves discarding applications from graduates because they have reached the age of 39. 
The rate of net discrimination against the 47-year-old waiter in London of 68.2 per cent is the highest ever recorded anywhere by the written experimental method. Table 2 indicates that McIntosh and Smith (1974) recorded a net rate of 30.0 percent for West Indians and Jowell and Prescott-Clarke (1970) recorded a rate of 11.0 percent for West Indians and 50.0 percent for Indians. Outside London discrimination was at the much lower rate of 13.8 percent so that the net rate for England was 28.8 percent.

In the case of retail sales we found a preference for the older applicant, which was statistically significant at the 0.05 level.

Although there are no other published experimental studies of age discrimination in employment available for comparative purposes, List (2004) has detected age discrimination in a product market experiment. He found that white males aged 60 and over encountered discrimination when they participated as either buyers or sellers in the sportscard market. This reinforces our finding that age discrimination is a serious phenomenon and needs to be addressed as vigorously as racial and sexual discrimination.

\section{Interpretation}

Warr (1994) presents a classification of job activity in four categories, based on the relationship of performance to age. First are "age-impaired activities" in which there is a negative relationship between age and performance; “... basic capacities are exceeded to a greater extent for older people and experience cannot help. Tasks of that kind include continuous rapid information processing and some forms of strenuous physical activity.” (Warr 1994, p. 314) “... complex tasks, requiring a large number or 
processing steps, are especially likely to be susceptible to cognitive slowing” (Warr 1994, p. 315). Second are "age-counteracted activities", in which there is no relationship between age and performance, because older people have strategies to compensate for any decline in information processing skills or in physical capacity. For example “...middle managers may learned to conserve their energy and time by operating through day-to- day tactics which reduce cognitive and affective load” (Warr 1994, p. 317). Third are "age-neutral activities", in which there is no relationship between age and performance, because the work is relatively undemanding and routine “...primary memory is apparently unaffected by age; older people are as able as their younger counterparts to hold in memory small amounts of information that are being used in uncomplicated cognitive activities” (Warr 1994, p. 317). Fourth are "age-enhanced activities” in which performance improves with age, because of the favorable impact of experience. Knowledge-based activity without time pressure comes within this category. For example; “... in a study of an American company's sales staff older employees were rated much more positively than younger ones in almost every respect” (Warr 1994, p. 316).

Warr's framework provides an explanation for age-related employment preferences which arise from age-related human capital differences. Becker and Arrow/Phelps have provided the economic bases for employment preferences which arise from discriminatory attitudes in the market place. Becker's (1971) theory proposes that customers, employers and/or current employees will sacrifice economic benefit, in order to indulge a "taste" for eschewing contact with some perceived pariah group. The Arrow/Phelps (1973/1972) hypothesis of "statistical discrimination" refers to the incomplete information, which employers have of the productivity and work 
characteristics of individual job applicants; this induces employers to resort to generalisations about the employment characteristics of groups, as a screening device to minimise the cost of information acquisition in the hiring process.

In the case of "new graduates", where we found a very high rate of discrimination against the older job applicant, it is not realistic to explain it by attribution to Warr's first category; the older graduate is 39 , and has just completed a degree in a rigorous discipline: economics or law. Also she engages in squash or contemporary dance, and learns Italian. It is difficult to credit that discrimination is "statistical" in the sense defined by Arrow (1973) and Phelps (1972). Both the "new graduate” women are in the fertile age range and, theoretically, equally prone to employment interruption, although the age of the older candidate's child might indicate she had done with planned child-bearing. The nature of this employment is that employee-customer contact is minimal to moderate, so it is unlikely that employers are being driven by any customer pressure; instead a clue might be found in the reply quoted above; delayed entry into higher education and experience of work being viewed as a disadvantage, as it might have imparted confidence, self-assurance and a degree of independence which could make life difficult for low-level managers, i.e. a variant of employer discrimination à la Becker (1971). Some confirmation of this hypothesis was found when graduates were interviewed about their experience of job search; “... some employers appear to have regarded mature graduates with suspicion, not only unsure about where they might fit into an organisation, but also wary of their motives for doing a degree and imputing character flaws in those who had not followed the "normal” (in fact middle-class) educational route from secondary school into higher education” (Purcell et al. 2003, p. 26). 
Waiters clearly come into Warr's category three, as the work is relatively undemanding and routine; also recall that our older waiter plays competitive squash, so his physical capacity to do the job can hardly be in doubt. The contrasting finding between London and the rest of England rules out "statistical discrimination"; it is not realistic to hypothesise that any constituents of incomplete information vary geographically, in such a way as to activate this reaction. As long ago as 1933 George Orwell in Down and Out in Paris and London, (1940, pp. 68-69) recognized the strange symbiosis between waiter and diner. It certainly is an occupation with a critical interaction between employee and customer, and in an economic activity where repeat business is vital for commercial success. There is critical interaction, for instance, between nurse and patient, but few of us are repeat customers of hospitals. This might suggest particular insight in the casual aside quoted at the outset of this paper, which comes from the television adaptation of Zadie Smith's novel White Teeth, that is, customer prejudice à la Becker.

In their econometric study, which used data from the Workplace Employment Relations Survey, Daniel and Heywood found “...strong evidence for the role of deferred compensation and internal labor markets as a negative predictor of hiring older workers. This fits the hypothesis that efficient life-time incentive structures require hiring younger workers and employing them when old, but not hiring older workers.” (Daniel and Heywood 2007, p. 49). However these factors cannot explain our results for graduates and waiters. Waiters do not operate in internal labor markets, nor do they benefit from deferred compensation. Our older graduate is 39, whereas Daniel and Heywood distinguish between those under 50, and those who are 50 or over. With more than twenty years until retirement our mature age graduate hardly fits 
the hypothesis that - “... the firm does not hire older workers because their shorter employment horizon means they are less well motivated by delayed compensation” (Daniel and Heywood 2007, p. 37).

The geographical variation between London and the rest of England is unprecedented in this type of experimental research. It may be partly explained by differential unemployment rates: for the period of this experiment (July-September 2004) the Labour Force Survey records a rate of 7.2 percent for men in London, in contrast to a rate of 4.4 percent for the rest of England (Labour Market Statistics 2005). When unemployment is high, and more applicants are searching, it facilitates the exercise of any discriminatory penchant which employers may have. Conversely when unemployment is low, and fewer applicants are searching, employers have less opportunity to discard applicants simply on the basis of some arbitrary characteristic such as race, sex or age. The higher rate for London may also be partly attributable to a greater devotion to pursuit of the fashionable "celebrity lifestyle" in the cosmopolitan capital, with its emphasis on the "youth culture", which reflects the younger age distribution of the London population. The proportion of the Inner London population aged 20-39 in 2001 was 41.3 percent; the proportion of the population in that age range for the rest of England was 27.5 percent (Census 2001).

Retail managers clearly come into Warr's category four and, significantly, it is sales staff whom he cites as his example of age-enhanced activity. Both our applicants had managerial backgrounds, and this is the most commercially-responsible job tested, so we interpret the preference for the older applicant as reflecting a realisation by employers that this is an employment where the job experience component of human 
capital contributes significantly to performance, which may include customer satisfaction. We have here a rational response to age-related human capital differences, rather than discrimination.

\section{Policy: implications and recommendations}

We found net discrimination against a 39-year-old graduate of 59.6 per cent and against a 47-year-old waiter, in London, of 68.2 percent. In the 1960s Political and Economic Planning (PEP), recorded discrimination of 90.0 per cent against Indians and Afro-Carribeans (Daniel 1968). The finding of that level of racial discrimination, by PEP, gave rise to considerable concern at the time: not least in the House of Commons during the Committee Stage and the Second Reading of the Race Relations Bill in 1967/8. All three major parties (including the Conservatives, who are ideologically committed to laissez faire) referred, with obvious concern to PEP's findings: Quentin Hogg the Conservative member for St. Marylebone (later Lord Hailsham, the Lord Chancellor) said, during the Committee stage; “... a great deal has happened in the last year. There has been the first Report of the Race Relations Board. There has been the PEP Report on Racial Discrimination ... I tell the right hon. Gentleman plainly that, originally I was very critical of fresh legislation on this subject so soon after the last. But I was immensely impressed by the quality of some of the documents to which I have referred” (Parliamentary Debates 15 November 1967). Subsequently during the Second Reading Debate he said; "I was convinced in the end by the evidence of the PEP report and the Street Report...that in the fields of housing and employment there are circumstances in which the economic laws would operate in favor of discrimination and against human rights” (Parliamentary Debates 23 April 1968). 
It was right and proper that the British nation's statesmen reacted so, and took legislative action to confront racial discrimination in 1968. It is not unreasonable to expect equivalent concern and reaction in 2007 in respect, not just of the elderly, but also of the "young seniors" (for example our waiters), and, in the case of the graduate, the middle-aged. They are more numerous and just as deserving of protection as the black community. The portents, however, are not good; the deadline for implementing a European Union Directive on age equality legislation, agreed in 2000, was December 2006; the British legislation only came into force in October 2006.

An abiding mantra of British governments for the past twenty-five years has been the need for a "flexible labor market". It is rarely defined, but it is demand-side flexibility which is always implied. One official definition is; "In a "flexible" labor market where employment is little regulated (in terms of pay, working hours, restrictions on dismissal etc.) the creation of low-paid, part-time, short-term or otherwise nonstandard jobs is unconstrained, and there is a high level of job turnover, employers screen less intensively before hiring” (OECD 1992, p. 207).

In the Green Paper, Simplicity, Security and Choice: Working and Saving for Retirement, the current British government has shown great concern for the demographic structure of the labor force; for instance, it estimates that the ratio of those 65 plus to those $15-64$, will rise from 24.4 percent in 2000 to 32.8 percent in 2025 and to 39.2 percent in 2050 (Department for Work and Pensions 2002, p. 16). As we saw in the Introduction, the Government considers it essential that employment rates of older workers rise to meet this demographic/pensions crisis. It follows that a government, which proselytises for demand-side labor market flexibility, and which 
wants to encourage people to work longer, has an obligation to ensure supply-side flexibility for older workers, so that they are not trapped in the unemployment pool, or in unsatisfactory or oppressive current employment.

Experimental research (e.g. McIntosh and Smith; Riach and Rich 1987, 2006) of the hiring process has repeatedly demonstrated the uninformative, and sometimes dishonest, nature of rejection letters. The pattern of dishonesty was repeated in this study. For example, in an application for a graduate position, the younger applicant was sent the following response on 11 November:

“Thank you for sending your CV to .... Can you call me to discuss ...”.

The older applicant was sent the following response on 19 November:

"I am writing to inform you that you have not been selected for a registration interview with ... on this occasion. Unfortunately your skills and experience to date do not exactly match our client's requirements at this time”.

On another occasion the older graduate was sent the following on 7 August:

“... I regret to advise you we have no vacancy for a trainee chartered accountant. We have now filled all our training places”.

Whereas on 12 August the younger applicant was sent:

"Due to holiday commitments, we are unable to offer you an interview until early September. If this is of interest to you, please contact ... to arrange an appointment”.

It follows that, in most cases, a rejected applicant would not be aware that they had incurred discriminatory treatment and, even if they did suspect it, they would lack evidence to demonstrate, before a legal tribunal, a prima facie case of discrimination. This is acknowledged, inter alia, by the OECD; “... age discrimination legislation 
may not be very effective since it is often easier to prove discrimination in dismissal than hiring” (OECD 2004, p. 99). It was also an important conclusion of Adams in his investigation of the impact of state age discrimination legislation in the USA. Using interstate data from as far back as the 1960s he concluded - "One thing is clear, however. There is no evidence that suggests there are positive effects for protected workers. The stock of older workers that are new hires did not change” (Adams 2004, p. 237). It follows that this is a particularly serious problem for policy to address, especially in view of the rates of discrimination detected in our experiment for people as young as 39 and 47. Nevertheless, the British age discrimination legislation of 2006 requires the complainant to prove facts from which the Employment Tribunal could conclude that the respondent has discriminated.

Consequently a new approach is required and we recommend that, to strengthen the effectiveness of age discrimination legislation, in respect of recruitment, any equal opportunity, or human rights, commission should be charged to play an active, investigative role in the recruitment process; that is, it should have power to conduct random audits of hiring and personnel practices. If employers were required to keep all records of job applications for a period of twelve months, and obliged to justify decisions on short-listing for interview and final choice of candidate, in the event of random audit, it would create pressure for scrupulousness in the hiring decision. An appropriate analogy can be drawn here with the capital market. Public corporations have various duties with respect to reporting to shareholders, potential shareholders and the business community at large. They are also subject to independent financial audit, and they are usually required to satisfy an independent commission about various aspects of their financial activities. In effect, capitalist economies provide a 
range of regulations and checks to protect the owners of financial capital against unscrupulous practices and guard against the waste of this resource. Therefore it seems entirely appropriate that similar protection be afforded the owners of human capital, and that steps be taken to prevent it being wasted through employers using screening devices, such as race, sex or age, for purposes unrelated to job performance. Barbara Bergmann has also advocated a similar policy (see Bergmann 1986, p. 158).

A complementary recommendation is that the approach to combating age discrimination in recruitment should be one of affirmative action. Affirmative action inevitably invokes fierce controversy and opposition from the privileged group usually white, middle-class, “prime-age”, protestant men.

In an investigative, or audit strategy, we recommend that employers should be required to justify why appropriately-qualified post-40/post-50/post-60 applicants have not been appointed. If the proportion of post/40/50/60 appointments is less than (say) 66 percent of the proportion of appropriately-qualified post40/50/60 applications then the employer should be required to review personnel policies and an auditor would be involved in future selection procedures until significant improvement occurred. In other words we are recommending a form of affirmative action for the middle-aged and elderly. As Bergmann has explained - "The selection process often does have important subjective elements, allowing plenty of leeway for making mistakes as well as for decision-makers attitudes about race and gender to influence outcomes. Thus, it is wrong to assume that the candidate chosen in the absence of affirmative action is always or almost always better than all those sent away" (Bergmann 1986, p. 104). 
Age-based affirmative action would not incur some of the opposition traditionally directed at race or sex-based affirmative action. We are only recommending that older applicants be given proportionate treatment in jobs which they have already been doing, or perhaps, at most, one step up in the hierarchy. The charge that they "only got the job because of their age” could not hold up: they have already demonstrated they have done the job. The other side of this coin is that the aged will not react, as some blacks and females do, in opposing affirmative action, because of their concern that it suggests they did not get the job on their merits. In this case their "merits" have previously passed muster.

Another significant distinction in respect of age-based affirmative action is that, whereas whites never become black, and only rarely do males become female, the young do become old. In other words we should expect lesser hostility from the "majority" group, as in this case they stand to benefit in their turn. Moreover in the current demographic environment the alternative to ensuring a fair employment deal for "older" workers are increased taxes to finance the growing pension bill. 
Table 1: Results for the Age Discrimination Tests

\begin{tabular}{|c|c|c|c|c|c|c|c|}
\hline $\begin{array}{c}1 \\
\text { Occupation }\end{array}$ & \begin{tabular}{l}
$\quad 2$ ' \\
\multicolumn{1}{c}{ Location of } \\
test
\end{tabular} & \begin{tabular}{l}
\multicolumn{1}{c}{3} \\
Neither \\
invited
\end{tabular} & $\begin{array}{l}\quad 4 \\
\text { Usable } \\
\text { tests }\end{array}$ & $\begin{array}{c}5 \\
\text { Equal } \\
\text { treatment }\end{array}$ & \begin{tabular}{l}
\multicolumn{1}{c}{6} \\
Discrimination \\
against older
\end{tabular} & \begin{tabular}{c}
\multicolumn{1}{c}{7} \\
Discrimination \\
against younger
\end{tabular} & $\begin{array}{c}8 \\
\text { Net } \\
\text { Discrimination }^{\mathrm{a}}\end{array}$ \\
\hline $\begin{array}{l}\text { Graduate } \\
\text { Total (number) }\end{array}$ & & & & & & & \\
\hline Percent & England & 373 & $\begin{array}{r}47 \\
100\end{array}$ & $\begin{array}{l}15 \\
31.9\end{array}$ & $\begin{array}{l}30 \\
63.8\end{array}$ & $\begin{array}{l}2 \\
4.3\end{array}$ & $\begin{array}{l}28 \\
59.6 * * *\end{array}$ \\
\hline Retail Manager & & & & & & & \\
\hline $\begin{array}{l}\text { Total (number) } \\
\text { Percent }\end{array}$ & London & 273 & $\begin{array}{r}27 \\
100\end{array}$ & $\begin{array}{c}3 \\
11.1\end{array}$ & $\begin{array}{c}8 \\
29.6\end{array}$ & $\begin{array}{l}16 \\
59.3\end{array}$ & $\begin{array}{l}-8 \\
-29.6^{*}\end{array}$ \\
\hline $\begin{array}{l}\text { Waiter } \\
\text { Total (number) } \\
\text { Percent }\end{array}$ & England & 390 & $\begin{array}{r}80 \\
100\end{array}$ & $\begin{array}{l}11 \\
13.8\end{array}$ & $\begin{array}{l}46 \\
57.5\end{array}$ & $\begin{array}{l}23 \\
28.8\end{array}$ & $\begin{array}{l}23 \\
28.8 * * *\end{array}$ \\
\hline $\begin{array}{l}\text { Total London (number) } \\
\text { Percent }\end{array}$ & London & & $\begin{array}{r}22 \\
100\end{array}$ & $\begin{array}{c}3 \\
13.6\end{array}$ & $\begin{array}{l}17 \\
77.3\end{array}$ & $\begin{array}{l}2 \\
9.1\end{array}$ & $\begin{array}{l}15 \\
68.2^{* * *}\end{array}$ \\
\hline $\begin{array}{l}\text { Total Rest of England (number) } \\
\text { Percent }\end{array}$ & & & $\begin{array}{r}58 \\
100\end{array}$ & $\begin{array}{c}8 \\
13.7\end{array}$ & $\begin{array}{l}29 \\
50\end{array}$ & $\begin{array}{l}21 \\
36.2\end{array}$ & $\begin{array}{c}8 \\
13.8\end{array}$ \\
\hline
\end{tabular}

Note 1: Chi-squared tests were conducted on the response rates and the results are indicated in column 8 - * significant at the 0.05 level; ** significant at the 0.01 level; *** significant at the 0.001 level.

a. A negative value indicates discrimination against the younger applicant. 
Table 2: Results for the UK Sex and Race Discrimination Tests

\begin{tabular}{|c|c|c|c|c|}
\hline Occupation & Study & Location of test & Test on basis of & $\begin{array}{c}\text { Net Discrimination } \\
\text { percent } \\
\end{array}$ \\
\hline Chartered accountant & $\begin{array}{l}\text { Riach and Rich } \\
\text { (2006) }\end{array}$ & England & Sex & $-20.0^{*^{\mathrm{a}}}$ \\
\hline Computer analyst programmer & $\begin{array}{l}\text { Riach and Rich } \\
\text { (2006) }\end{array}$ & $\begin{array}{l}\text { London and South } \\
\text { East }\end{array}$ & Sex & $-35.3^{* *^{\mathrm{a}}}$ \\
\hline Engineer & $\begin{array}{l}\text { Riach and Rich } \\
\text { (2006) }\end{array}$ & $\begin{array}{l}\text { London, South, } \\
\text { South-East, Home } \\
\text { Counties }\end{array}$ & Sex & $23.1^{*}$ \\
\hline Secretary & $\begin{array}{l}\text { Riach and Rich } \\
\text { (2006) }\end{array}$ & London & Sex & $-43.1^{* * * a}$ \\
\hline $\begin{array}{l}\text { Accountant, Electronics } \\
\text { Engineer, Sales representative, } \\
\text { Secretary }\end{array}$ & $\begin{array}{l}\text { Jowell and Prescott- } \\
\text { Clarke (1970) }\end{array}$ & England & $\begin{array}{l}\quad \text { Race } \\
\text { Asian } \\
\text { West Indian }\end{array}$ & $\begin{array}{l}50.0^{* * * *} \\
11.0\end{array}$ \\
\hline $\begin{array}{l}\text { Clerk, Sales Representative, } \\
\text { Secretary, Shop assistant }\end{array}$ & $\begin{array}{l}\text { Hubbuck and Carter } \\
\text { (1980) }\end{array}$ & Nottingham & $\begin{array}{l}\quad \text { Race } \\
\text { Asian } \\
\text { West Indian }\end{array}$ & $\begin{array}{l}42.0 * * * \\
43.0 * * *\end{array}$ \\
\hline $\begin{array}{l}\text { Accountant, Clerical, } \\
\text { Management Trainee, } \\
\text { Salesman, Secretary }\end{array}$ & $\begin{array}{l}\text { McIntosh and Smith } \\
\text { (1974) }\end{array}$ & $\begin{array}{l}\text { Birmingham } \\
\text { London }\end{array}$ & $\begin{array}{c}\text { Race } \\
\text { Asian/West Indian }\end{array}$ & $30.0 * * *$ \\
\hline
\end{tabular}

Note 1: Chi-squared tests were conducted on the response rates and the results are indicated for net discrimination:

* significant at the 0.05 level; ** significant at the 0.01 level; *** significant at the 0.001 level.

a. A negative value indicates discrimination against the male applicant. 
Table 3: Results for the Age Discrimination Tests for Graduates, for Firms Noted as "Investors in People"

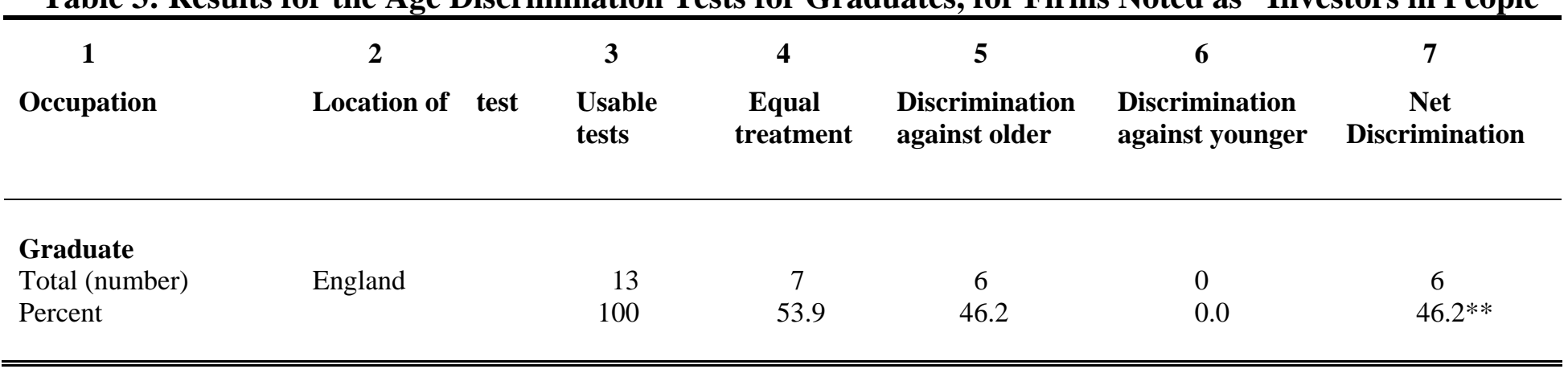

Note 1: Chi-squared tests were conducted on the response rates and the results are indicated in column 8:

* significant at the 0.05 level; ** significant at the 0.01 level 


\section{Appendix \\ Two Résumés Used in Job Applications for Waiter}

\section{Résumé A}

Personal Profile of ...

Personal details

Born 13-4-1977

email

\section{Qualifications}

GCSE - 6 Subjects two of which were English and Mathematics NVQ3 in Hospitality Supervision

NVQ2 in Food and Drink Services

'Computer Usage and Fine Wines of the World' studied in my course at College

\section{Employment}

2001 - present: Senior Waiter at Restaurante Venezia in Tunbridge Wells.

1997- 2000: Waiter at a restaurant in Brighton, which I moved to in order to gain a more responsible post, and to have experience of serving foreign food and fine wine. 1994 -1997: My first job was at a hotel in Brighton, where I initially served breakfast and afternoon tea, but was soon promoted to serving lunch and dinner.

\section{Sporting and cultural interests}

Mountain-biking and films. 


\section{RÉSUMÉ B}

RÉSUMÉ OF .......

ADDRESS

EMAIL

AGE $\quad 47$

EDUCATION

5 “O” levels (including English and Maths)

Evening classes at College - including food service, wine appreciation, restaurant management and computer skills.

NVQ2 in Food and Drink Services and NVQ3 in Restaurant Supervision.

\section{EXPERIENCE}

After leaving school I had a variety of jobs such as coffee shop server and barman. I became a waiter in 1988 and since then have had a variety of jobs in hotels and restaurants, serving English, French, Italian and Spanish food. I began in hotels in Torquay, Bath and Burford. My duties included, preparing the dining room and serving breakfast, lunch and dinner. I also helped with room service. Subsequently I moved to more senior and responsible jobs in restaurants in London, Oxford and Stratford-upon-Avon, serving food and wine. For the last three years I have been employed at "Claudettes" in Guilford as Deputy Head Waiter.

\section{INTERESTS}

I play competitive Squash and I enjoy restoring classic motor cycles. Also I enjoy using the internet. 


\section{References}

Adams, Scott J. (2004). 'Age Discrimination Legislation and the Employment of Older Workers’, Labour Economics, Vol. 11, No.2, pp. 219-241.

The B.E. Journal of Economic Analysis and Policy, (2006), Vol. 6, Issue 2. www.bepress.com/bejeap/advances/6,issue2

Arrow, Kenneth (1973). 'The Theory of Discrimination, in Ashenfelter, Orley and Rees, Albert (eds.), Discrimination in Labor Markets, Princeton University Press, Princeton, pp. 3-33.

Becker, Gary (1971). The Economics of Discrimination, $2^{\text {nd }}$ edition. University of Chicago Press, Chicago.

Bendick Jnr. Mark, Jackson, Charles and Romero, J. H. (1996). 'Employment Discrimination Against Older Workers: An Experimental Study of Hiring Practices', Journal of Aging and Social Policy, Vol. 8, No. 4, pp. 25-46.

Bendick Jnr. Mark, Brown, Lauren and Wall, Kennington (1999). 'No Foot in the Door: An Experimental Study of Employment Discrimination Against Older Workers', Journal of Aging and Social Policy, Vol. 10, No. 4, pp. 5-23.

Bergmann, Barbara (1986). The Economic Emergence of Women. Basic Books, New York. 
Blinder, Alan (1973). 'Wage Discrimination: Reduced Form and Structural Estimates', Journal of Human Resources, Vol. 8, pp. 436-455.

Bovenkerk, Frank (1992). Testing Discrimination in Natural Experiments: A Manual for International Comparative Research on Discrimination on the Grounds of 'Race’ and Ethnic Origin. International Labour Office, Geneva.

Brown, Colin and Gay, Pat (1985). Racial Discrimination 17 Years After the Act. Policy Studies Institute, London.

Census 2001. http://www.statistics.gov.uk/census2001/

Daniel, Kirsten and Heywood, John S. (2007). 'The Determinants of Hiring Older Workers: UK Evidence', Labour Economics, Vol.14, No. 1, pp. 35-51.

Daniel, W. W. (1968). Racial Discrimination in England. Penguin Books, England.

Darity Jr., William A. and Mason, Patrick L. (1998). 'Evidence on Discrimination: Codes of Color, Codes of Gender', Journal of Economic Perspectives, Vol. 12, No. 2, pp. 63-90.

Department for Work and Pensions (2002). Simplicity, Security and Choice: Working and Saving for Retirement. HMSO, London. 
Fidell, L. S. (1970). 'Empirical Verification of Sex Discrimination in Hiring Practices in Psychology’, American Psychologist', Vol. 25, December, pp. 1094-98.

Goldberg, Andreas, Mourinho, Dora and Kulke, Ursula (1996). Labour Market Discrimination Against Foreign Workers in Germany. International Migration Papers 7. International Labour Office, Geneva.

Gunderson, Morley (1989). 'Male-Female Wage Differentials and Policy Responses’, Journal of Economic Literature, Vol. 27, pp. 46-72.

Higher Education Statistics (2002/03). Statistics on Students in Higher Education in the United Kingdom. Unpublished data. Higher Education Statistics Agency (HESA), Cheltenham, UK.

Hubbuck, Jim and Carter, Simon (1980). Half a Chance? A Report on Job Discrimination against Young Blacks in Nottingham. Commission for Racial Equality, London.

Investors in People. 2005. http://www.iipuk.co.uk

Jowell, Roger and Prescott-Clarke, Patricia (1970). 'Racial Discrimination and WhiteCollar Workers in Britain', Race, Vol. 11, No. 4, pp. 397-417. 
La Piere, Richard (1934). 'Attitudes vs Actions', Social Forces, Vol. 13, No. 2, pp. 230-237.

Labour Market Statistics (2005). http://www.statistics.gov.uk/

List, John (2004). 'The Nature and Extent of Discrimination in the Marketplace: Evidence from the Field', Quarterly Journal of Economics, Vol.119, No. 1, pp. 49-89.

McIntosh, Neil and Smith, David (1974). 'The Extent of Racial Discrimination', Political and Economic Planning Broadsheet no.547, Political and Economic Planning, London.

Oaxaca, Ronald (1973). 'Male-Female Wage Differentials in Urban Labor Markets', International Economic Review, Vol. 14, No. 3, pp. 693-703.

OECD (2004). Ageing and Employment Policy, United Kingdom. Paris, OECD.

OECD (1992). The Job Study, Part 11 - The Adjustment Potential of the Labour Market. OECD, Paris.

Orwell, George (1940). Down and Out in Paris and London. Penguin, Harmondsworth, UK. 
Parliamentary Debates (1968). Volume 763, column number 78, 23 April. HMSO, London.

Parliamentary Debates (1967). Volume 754, column number 452, 15 November. HMSO, London.

Penna Sanders and Sidney (2002). 'Generation Flex to the Rescue?' http://www.management-issues.com.

Phelps, Edmund (1972). ‘The Statistical Theory of Racism and Sexism', American Economic Review, Vol. 62, No. 4, pp. 659-661.

Purcell, Kate, Wilton, Nick and Elias, Peter (2003). Older and Wiser? Age and Experience in the Graduate Labour Market. Researching Graduate Careers Seven Years On. Research paper no. 2. Warwick University, Warwick Institute for Employment Research.

Riach, Peter A. and Rich, Judith (2004a). 'Deceptive Field Experiments of Discrimination: Are They Ethical?’, KYKLOS, Vol. 57, Issue 3, pp. 457-470.

Riach, Peter A. and Rich, Judith (2004b). 'Fishing for Discrimination', Review of Social Economy, Vol. 61, No. 4, pp. 465-486.

Riach, Peter A. and Rich, Judith (2002). 'Field Experiments of Discrimination in the Market Place’, Economic Journal, Vol. 112, No. 483, pp. F480-F518. 
Riach, Peter A. and Rich, Judith (1987). 'Testing for Sexual Discrimination in the Labour Market', Australian Economic Papers, Vol. 26, No. , pp. 165 - 178.

Smith, Zadie (2000). White Teeth. Hamish Hamilton, London.

Third Age Employment Network (2003). Experience of Age Discrimination: The Evidence. February, http://www.taen.org.uk

Warr, P. (1994). ‘Age and Job Performance’, In: Snel, Jan and Cremer, Roel (eds.), Work and Aging: A European Perspective, Taylor and Francis, London, pp. 309-322. 